\title{
RAPT IN PLAID
}

\section{Canadian Literature and Scottish Tradition}

Rapt in Plaid combines reflection, criticism, and memoir to illustrate a curious and long-lasting connection between Scottish and Canadian literary traditions. Examples drawn from genres including lyric poetry, narrative romance, war fiction, children's literature, sentimental fiction, thrillers, domestic novels, and short stories link Canadian writers such as John Richardson, Isabella Valancy Crawford, Sinclair Ross, Hugh MacLennan, Margaret Laurence, and W.O. Mitchell to Scottish writers such as Robert Burns, Walter Scott, Thomas Carlyle, J.M. Barrie, Robert Louis Stevenson, John Buchan, and George Mackay Brown.

Each chapter traces the connections from directly imitative nineteenth-century Canadian writers to modern Canadian works where Scottish tradition persists, sometimes transformed and sometimes distorted. Lively biographical sketches and close analysis of particular passages by Scottish and Canadian writers are set in the context of multicultural, narrative, postmodern, and post-colonial theories. This study illuminates the way Scottish ideas and values still wield surprising power in Canadian politics, education, theology, economics, and social mores.

Although Professor Waterston's method is that of a literary historian, she frames each section in this new work with affectionate memories of reading, researching, and teaching Scottish and Canadian literature over a sixty-year period.

elizabeth waterston is Professor Emeritus, University of Guelph. A lifetime member of the Association of Canadian Studies and a former National President of the Humanities Association of Canada, she is also a co-founder and former editor of Canadian Children's Literature / Littérature canadienne pour la jeunesse. 
This page intentionally left blank 


\section{Rapt in Plaid}

Canadian Literature and

\section{Scottish Tradition}

ELIZABETH WATERSTON

UNIVERSITY OF TORONTO PRESS

Toronto Buffalo London 


\section{www.utppublishing.com}

(C) University of Toronto Press Incorporated 2001

Toronto Buffalo London

Printed in Canada

Reprinted in paperback 2003

ISBN 0-8020-4785-8 (cloth)

ISBN 0-8020-8685-3 (paper)

(6)

Printed on acid-free paper

\section{National Library of Canada Cataloguing in Publication}

Waterston, Elizabeth, 1922-

Rapt in plaid : Canadian literature and Scottish tradition / Elizabeth Waterston.

Includes bibliographical references and index.

ISBN 0-8020-4785-8 (bound).-ISBN 0-8020-8685-3 (pbk.)

1. Canadian literature (English) - Scottish influences. 2. Canadian literature (English) - History and criticism. 3. Literature, Comparative - Scottish and Canadian (English). 4. Literature, Comparative Canadian (English) and Scottish. 5. Scottish literature - History and criticism. 6. English literature - Scottish authors - History and criticism. I. Title.

PS8097.S36W37 2000 C810.9 C00-932193-4

University of Toronto Press acknowledges the financial assistance to its publishing program of the Canada Council for the Arts and the Ontario Arts Council.

This book has been published with the help of a grant from the Humanities and Social Sciences Federation of Canada, using funds provided by the Social Sciences and Humanities Research Council of Canada.

Support of this publication by the Scottish Studies Foundation is gratefully acknowledged.

The University of Guelph Research Board awarded a grant in aid of publication from the General Research Grant of the Social Sciences and Humanities Research Council.

University of Toronto Press acknowledges the financial support for its publishing activities of the Government of Canada through the Book Publishing Industry Development Program (BPIDP). 